Journal of Humanities, Social and Management Sciences (JHSMS)

eISSN: 2788-4791 (online)

https:// doi.org/10.47264/idea.jhsms/3.1.6

Vol. 3, No. 1 (January-June 2022), 71-83

https://ideapublishers.org/index.php/jhsms

Research Article

\title{
Assessment of woman political participation in 2018 Elections and its comparison with elections of 2002,2008 and 2013
}

\author{
Seema Gul*1 | Tatheer Zahra Sherazi ${ }^{2}$
}

1. Department of Political Science, University of Peshawar, Peshawar, Pakistan.

2. Department of International Relations, National University of Modern Languages, Islamabad, Pakistan.

*Corresponding Author Email: seema.ghani86@gmail.com

Received: December 6, 2021

Accepted: February 1, 2022

Published: February 26, 2022

\begin{abstract}
Women's political participation strengthens their political as well as their empowerment in other fields of life. The discourse of women's political participation is a matter of concern in the academic circles across the world. The main aim of this study is to provide a complete analysis of changing orientation in the women politics of Charsadda, Khyber Pakhtunkhwa (KP), Pakistan. This study focuses on the effect of political reforms on women's political participation in Pakistan. Furthermore, this study focuses on the effect of political reforms on women's public and civic engagements which further contribute to their political participation. The main question that guides the study is that how can political participation of women transform the public sphere of KP, and how would then the transformed public sphere (i.e., the greater political participation of women) enhance democratic politics of KP? Feminist theories i.e., Liberal Feminist Theory and Radical Feminist Theories are used as theoretical framework in this study to examine the question of the effect of political reforms on women's political participation. The study finds positive effects of the political reforms on women, like awareness about these reforms and civic engagements. The study recommends that women political participation could be enhanced by improving their level of education.
\end{abstract}

Keywords: democracy, political participation, women political participation, gender gap, general election, women election.

How to Cite: Gul, S. \& Sherazi, T. Z. (2022). Assessment of woman political participation in 2018 Elections and its comparison with elections of 2002, 2008 and 2013. Journal of Humanities, Social and Management Sciences (JHSMS), 3(1), 71-83. https://doi.org/10.47264/idea.jhsms/3.1.6

Publisher's Note: IDEA PUBLISHERS (IDEA Publications Group) stands neutral with regard to jurisdictional claims in the published maps and institutional affiliations.

Copyright: ( 2022 The Author(s), published by IDEA PUBLISHERS (IDEA Publications Group).

Licensing: This is an Open Access article published under the Creative Commons AttributionNonCommercial 4.0 International License (http://creativecommons.org/licenses/by-nc/4.0/) 


\section{Introduction}

This article attempts to assess women political participation in four the general elections of Pakistan of $21^{\text {st }}$ Century. The study aims to investigate that what are the factors which increases and decreases women turnout in elections as compared to men. Through data, the research study aims to understand the causes of this low turnout in general elections in Pakistan while taking the elections of 2018 as a case study. The focus of the research article is Khyber Pakhtunkhwa province of Pakistan populated by majority ethnic Pashtuns.

One of the basic factors involved in political development of a society relates to women's participation in politics and decision-making roles. However, we know that this factor is weak in patriarchal societies that deny women the right to participate in politics. By public sphere we mean that space in society where both men and women come together to freely discuss and debate societal problems and then use this space for influencing political action. In other words, it is that domain of social life where public opinion can be formed (Habermas, 1991, p. 398). The history of women's electoral participation in Pakistan is not encouraging. Women's representations through reserved seats began during the colonial time. Though there were limited seats in the 1919 Montague Chelmsford Reforms, but in the 1935 Act for the first-time reserved seats for women were included. In all the three Constitutions of Pakistan i.e., 1956, 1962 and 1973, there have been reserved seats for women.

During Musharraf's regime, women reserved seats quota increased to sixty. Women representation in provinces was also high as total of 139 women MPAs, in which 66 for Punjab, 29 for Sindh, 22 for KPK, and 11 for Baluchistan (Waseem, 2006). Much of the literature on women participation in politics in Pakistan does not directly engage the concept of public sphere or its importance. For instance, Bano (2009) focuses on how different governments of Pakistan used women political roles to strengthen their own regimes. Bari (2005) focuses on how democracy like other forms of government has only enabled and facilitated men to the neglect of women. Other scholars like Waseem (2006), Choudhary (2018) and Mahmood (2018). Similarly, Latif et al. (2015) also figures out on the relationship of democracy and women's participation in the context of Pakistan. They point to meagre opportunities available to women in politics, but do not point to how women could create their own space in politics.

\subsection{Significance of the study}

The study will enable the researchers and policymakers to know about the changing orientations and dimensions in women politics in Khyber Pakhtunkhwa. Like many other provinces of Pakistan in KPK there is also general concept prevailing that women's place is home, while men are supposed to work outside and to look after the family, and this is the main reason that restrict women political participation. There are cultural, religious, and economical barriers which limit women political participation in Pakistan general and in Khyber Pakhtunkhwa particular and women of this areas faces many challenges for example patriarchy, gender discrimination, lack of education and awareness.

\subsection{Research gap}

Enough literature is available on the subject, but no study has been conducted on the proposed topic. Report of various organizations on 2002, 2008, 2013 and 2018 general elections declared 
that women's participation in politics have strengthened its roots in Pakistan. Khyber Pakhtunkhwa is the most affected province of Pakistan in the war against global terrorism nevertheless in the 2013 and 2018 general elections, the province especially witnessed increase in women's political participation. An encouraging number of women casted their votes, contested elections, and launched elections campaigns. All these developments have challenged the existing traditional moorings in the political culture of Pashtun society. The paper will explore the empowerment of women in historical perspective in Khyber Pakhtunkhwa, Pakistan. This research will highlight that why our society does or does not allow women to participate in electoral process equally as it does men. It will help the concerned authorities and administration to understand main constraints to women electoral participation and they will be able to overcome those constraints.

\section{Methodology}

This research study is based on mixed method, using both qualitative and quantitative methods. On the quantitative side, the study will carry out a survey, and on the qualitative side, it will carry out ethnographic method. The purpose of using the mixed method is to understand the problem in its given culture or multifarious conditions. The researcher already has the background knowledge of the history, culture, and politics of Khyber Pakhtunkhwa, Pakistan because she belongs from there. This research methodology would be carried out in two stages.

\subsection{Quantitative method}

Quantitative survey method will be applied in this research. The survey method is the collection of information from a selected sample of population where their responses to questions are recorded through questionnaires (Check \& Schutt, 2012, p. 160). Quantitative research strategies will be used by developing questionnaire with numerically rated items. The Survey research method will be applied in this research because of the following reasons a) to achieve high level of accuracy, b) suitability for analysis in the present study, c) the study involves behaviour of the people, d) for participant's easiness, and e) that respondents can be honest and flexible in this method of research.

\subsection{Qualitative method}

In the present study the researcher employs grounded theory because it suits the subject matter. Grounded theory is developed as a methodology in social sciences by two sociologists, Barney Glaser and Anselm Strauss. It is called grounded theory because it is grounded in data. It helps the researcher to move from data to theory by progressive identification and integration of categories of meaning. This method is useful when there are no existing theories or limited number of theories and they do not satisfy researchers about the given issue. Grounded theory creates the possibility of developing contextualized theories (Glaser, 1992; Strauss \& Corbin, 1998; Charmaz, 2006).

\section{Results and discussion}

The general elections of 2018 give main concentration to the woman political participation. The government of Pakistan passed the Elections Act of 2017 for the purpose to increase voter registration as well as voter turnout. The Election Act of 2017 introduced three key measures. 
According to this act the constituency where women participation in election (turnout) is less than or equal to $10 \%$, that result will not be acceptable and will be annulled. This act also criminalized those persons, tribes, or any society who create problems for women to cast vote in the elections. It also directed all political parties to allocate at least 5\% of their non-reserved seats to NA and PAs. In most parts of Pakistan especially the people of rural areas women are restricted their women to cast their votes because they of the view that presence of males in the polling station there are males so keeping in view this point the Election Commission of Pakistan (ECP) appointed women staff for polling station. All these reasons are responsible for increased female registration in 2018 general election which was 66\% as compared to 2013 general election in Pakistan's north-western tribal areas the Federally Administered Tribal Areas (Now part of Khyber Pakhtunkhwa province). So, total $44 \%$ women registered in Pakistan as compared to $43.6 \%$ in 2013 general election. Similarly, in 2018 general election voter turnout was 23.26 million as compared to 22.9 million. In the Sindh's constituency Tharparker and in Punjab's constituencies included Bhakkar, Attock, and Bahawalpur the highest voter turnout recorded in 2018 general elections.

Being a part of half state population, the strength of women voters is not half. But the gap between male and female voters is vast. Voters registered for the general election of 2002 were 71.9 million. Male were included 38.8 million (53.9\%) out of 71.9 million voters and 33.2 million $(46.1 \%)$ were female voters. Therefore, there were 5.6 million $(7.6 \%)$ differences between men and women registered voters. Under general election 1997 the differences between men and women voters was $11 \%$ or 06 million voters (UNDP Pakistan, 2005). So, there is a 71.9 considerable increase in the voter's registration number under 2002 general election as compared to 56.6 million voters in 1997 general election. The main reason behind this development may be the relaxation in the age limit as decreased from 21 to 18 years (www.ecp.org.pk, 2002).

Table-1: Female voter turnout in General Election 2002

\begin{tabular}{|l|c|c|c|c|c|c|}
\hline Province/ICT & Islamabad & Punjab & Sindh & $\begin{array}{c}\text { NWFP (KP) } \\
\text { \& FATA }\end{array}$ & Baluchistan & Total \\
\hline Total Voters & 384070 & 41253858 & 16141566 & 10207513 & 3926843 & 71913850 \\
\hline Male Voters & 203900 & 21874446 & 8765729 & 5795641 & 2124021 & 38763737 \\
$(53.1 \%)$ & $(53.0 \%)$ & $(54.3 \%)$ & $(59.6 \%)$ & $(53.9 \%)$ & $(54.78 \%)$ \\
\hline Female Voters & 180170 & $\begin{array}{c}19379412 \\
(46.9 \%)\end{array}$ & $\begin{array}{c}7375837 \\
(47.0 \%)\end{array}$ & $\begin{array}{c}3421872 \\
(45.7 \%)\end{array}$ & $\begin{array}{c}33160113 \\
(40.4 \%)\end{array}$ & $\begin{array}{c}63517404 \\
(45.22 \%)\end{array}$ \\
\hline Total in Millions & 0.38 & 41.25 & 16.14 & 10.20 & 3.92 & 71.87 \\
\hline
\end{tabular}

Sources: General Election, 2002 Report Election Commission of Pakistan

In the general election of 2008, there were total 120.7 million registered voters in which the part of male voters was 73.1 million and the part of female voters were 47.6 million (www.ecp.org.pk, 2008). Like many others election held in Pakistan there was a big difference between male and female registered voters for the general election 2008 as fewer women registered than men and the disparity ratio was 25.5 million. This reduction in voter registration especially in the female voters was occurred due to some reason as military operation was start in FATA, the impact of 9/11 attacks was still feeling, and the Internal Displacement of People (IDPs) were responsible for female voter reduction at $96 \%$ in FATA, Pakistan. The same situation was in Khyber Pakhtunkhwa (EX-NWFP) and this was the most targeted province in the war against terrorism where approximately $45 \%$ female voter registered. If we compare female voter registration of 2002 with 2008 it was 3.92 million in 2002. Similarly, in other 
provinces and in even in Islamabad reduction was also seen (NCSW, 2010, p. 10). In Islamabad it was reduced to 19\%, in Punjab 37\%, and 41\% in Sindh. In the general election of 2008, male voters $18 \%$ and female voters $39 \%$ reduced as compared to 2002 general election ratio was $40 \%$ and $30 \%$ respectively (FAFEEN, 2010). As compared to urban areas of Pakistan in the rural areas in 2008 general election turnout of registered female voters recorded low as $10 \%$ (News Week, 2013). But some another source declared that female turnout was $12.8 \%$ in 2008 general elections, and it is inspiring one as in the last few election females turn out remained below 10\% (Kausar, 2013). The ECP for the 2008 general election arranged total 29,000 polling station for women and it was a disappointing news that in which 564 out of 29,000 polling stations no women came and cast her vote (Kausar, 2013).

Table-2. Female voter turnout in General Election 2008

\begin{tabular}{|l|l|l|l|l|l|l|}
\hline Province & Islamabad & Punjab & Sindh & $\begin{array}{l}\text { NWFP \& } \\
\text { FATA }\end{array}$ & Baluchistan & Total \\
\hline $\begin{array}{l}\text { No. of registered } \\
\text { voters }\end{array}$ & 482801 & 44485869 & 19506473 & 12071538 & 4363610 & 80910791 \\
\hline No. of Men voters & 261697 & 24481520 & 10894176 & 7310176 & 2358971 & 45306540 \\
\hline $\begin{array}{l}\text { No. of Women } \\
\text { voters }\end{array}$ & 221104 & 20004376 & 8612297 & 4761362 & 2004639 & 35603778 \\
\hline Total Voters Turnout & $\begin{array}{l}383603 \\
(51.2 \%)\end{array}$ & $\begin{array}{l}20931539 \\
(46.52 \%)\end{array}$ & $\begin{array}{l}8467146 \\
(45.52 \%)\end{array}$ & $\begin{array}{l}3380358 \\
(34.07 \%)\end{array}$ & $\begin{array}{l}1379808 \\
(31.62)\end{array}$ & $\begin{array}{l}34542454 \\
(42.2 \%)\end{array}$ \\
\hline
\end{tabular}

Sources: General Election, 2008 Report. Election Commission of Pakistan

In the 2013 general elections, the number of male registered voters were 48.6 million and females were 37.6 million. Women constitute $51 \%$ so, approximately 10 million females were missing as registered voters (Yousaf, 2013). In the four provinces of Pakistan 44.7\% in Sindh, 43.8\% in Punjab, 42.9\% in Khyber Pakhtunkhwa and 42.6\% in Baluchistan (FAFEEN, 2013).

Table-3: Female voter turnout in General Election 2013

\begin{tabular}{|l|c|c|c|c|c|c|}
\hline Province & Islamabad & Punjab & Sindh & $\begin{array}{c}\text { NWFP \& } \\
\text { FATA }\end{array}$ & Baluchistan & Total \\
\hline $\begin{array}{l}\text { No. of } \\
\text { registered voters }\end{array}$ & 625,964 & $49,259,334$ & $18,963,375$ & $14,004,470$ & $3,336,659$ & $86,189,802$ \\
\hline $\begin{array}{l}\text { No. of Men } \\
\text { voters }\end{array}$ & 337,900 & $27,697,701$ & $10,490,631$ & $8,150,767$ & $1,915,88$ & $48,592,387$ \\
\hline $\begin{array}{l}\text { No. of Women } \\
\text { voters }\end{array}$ & 288,064 & $21,561,633$ & $8,472,744$ & $5,853,703$ & $1,421,271$ & $37,597,415$ \\
\hline $\begin{array}{l}\text { Total Voters } \\
\text { Turnout }\end{array}$ & $\begin{array}{c}389,976 \\
(62 \%)\end{array}$ & $\begin{array}{c}28,760,265 \\
(60 \%)\end{array}$ & $\begin{array}{c}9,782,599 \\
(54 \%)\end{array}$ & $\begin{array}{c}5,984,014 \\
(45 \%)\end{array}$ & $\begin{array}{c}1,300,628 \\
(43 \%)\end{array}$ & $\begin{array}{c}46,217,482 \\
(53 \%)\end{array}$ \\
\hline
\end{tabular}

Sources: ECP General Election 2013, and FAFEEN observation report 2013

The general elections of 2018 give main concentration to the woman political participation. The government of Pakistan to increase voter registration as well as voter turnout passed the Elections Act of 2017. The Election Act of 2017 introduced three key measures. According to this act the constituency where women participation in election (turnout) is less than or equal to $10 \%$, that result will not be acceptable and will be annulled. This act also criminalized persons, tribe, or any society to create problems for women to cast vote in the election. It also directed all political parties to give at least $5 \%$ of their non-reserved for NA and PAs seats. In Pakistan especially the people of rural areas restricted their women to cast her vote because they of the view that in the polling station there are males so keeping in view this point the the 
Election Commission of Pakistan (ECP) appointed women staff for polling station (The Tabeer, 2018). All these reasons are responsible for increased female registration in 2018 general election as 66\% compared to 2013 general election in Pakistan's North-Western tribal areas the Federally Administered Tribal Areas (Now part of Khyber Pakhtunkhwa province). So, total 44\% women registered in Pakistan as compared to $43.6 \%$ in 2013 general election. Similarly, in 2018 general election voter turnout was 23.26 million as compared to 22.9 million. In the Sindh's constituency Thar parker and in Punjab's constituencies included Bhakkar, Attock, and Bahawalpur the highest voter turnout recorded in 2018 general elections (Mahmood, 2018).

Table-4: Female voter turnout in General Election 2018

\begin{tabular}{|l|l|l|l|l|l|l|}
\hline Province & Islamabad & Punjab & Sindh & $\begin{array}{l}\text { NWFP (KP) } \\
\text { \& FATA }\end{array}$ & Baluchistan & Total \\
\hline $\begin{array}{l}\text { No. of } \\
\text { registered } \\
\text { voters }\end{array}$ & 766,460 & $60,697,418$ & $22,394,212$ & $17,839,845$ & $2,668,834$ & $86,526,924$ \\
\hline $\begin{array}{l}\text { No. of Men } \\
\text { voters }\end{array}$ & 407,801 & $33,690,140$ & $12,438,375$ & $10,220,103$ & $2,487,470$ & $59,243,889$ \\
\hline $\begin{array}{l}\text { No. of Women } \\
\text { voters }\end{array}$ & 358,659 & $27,007,278$ & $9,955,837$ & $7,619,742$ & $1,813,264$ & $46,754,780$ \\
\hline $\begin{array}{l}\text { Total Voters } \\
\text { Turnout }\end{array}$ & $\begin{array}{l}445,827 \\
(58 \%)\end{array}$ & $\begin{array}{l}34,321,422 \\
(56.5 \%)\end{array}$ & $\begin{array}{l}10,55,4,507 \\
(47 \%)\end{array}$ & $\begin{array}{l}7,797,877 \\
(51 \%)\end{array}$ & $\begin{array}{l}1,854,889 \\
(43 \%)\end{array}$ & $\begin{array}{l}54,261,063 \\
(51.7 \%)\end{array}$ \\
\hline
\end{tabular}

Sources: FAFEEN, Election observation report 2018, www.ecp.com and Daily Pakistan

The same situation as also seen in some parts of Khyber Pakhtunkhwa and the Dir, Kohistan, and North and South Waziristan constituencies where it is recorded that many women used their right to vote for the first time in the history of Pakistan. The main reason was that there were some tribes and who prevented their women from political participation got their right to vote through the constitution of Pakistan in 1956 and the FATA in 1996. However, the election act of 2017 provided women's their political right. Due to these measures of ECP, some political parties of Pakistan including Allah-o-Akbar Tehreek, having links with the banned organization Jamaat-ut-Dawa, issued party tickets to 10 female candidates though they were against women's right to vote. But this privilege of giving party tickets to women were just a formality as they give seats to those women who were influential candidates and whose chances of winning their seats hundred percent. (Mahmood, 2018).

Like the last three general elections $(2002,2008,2013)$ in the 2018 general elections there were differences between men and female voter turnout was $56 \%$ and $47 \%$. Similarly, there were also differences among provinces of Pakistan. Probably $8 \%$ difference was recorded among Punjab, Sindh and Baluchistan between men and women while the voter turnout gap between men and women in Khyber Pakhtunkhwa had almost 19 per cent. The main feature of the 2018 general elections was the participation and turnout of gender-disaggregated and it was first time in the history of Pakistan that transgender got the right to vote (Dastageer et al., 2018). After the 2018 general elections, the ratio of those women candidates who won their seats decreased, but the ratio of contestant women candidates was increased. It is concluded from the 2018 general election that a total 464 women candidates contest the general election and make-5.2\%, in these 289 got party tickets given by political parties and 175 women decided to contest election as independents candidates and 5 transgenders also contest election. The 2018 general elections were conducted in peaceful environment because of the measures taken by the 
Election Commission. The most notable are increased voters' registration, women commissions, and civil society organizations. (Imran, 2018).

\subsection{Women electoral participation on General Seats as well as on reserved seats for the $15^{\text {th }}$ National Assembly of Pakistan}

The Election Commission of Pakistan (ECP) announced the date and issued a schedule for the general election 2018. Meetings and conversations started among different political parties of Pakistan. It was a difficult task for the political parties of Pakistan to give party tickets to women candidates for both reserved and general seats. After the election in 2017, all political parties of Pakistan including three major political parties, Pakistan People Party (PPP), Pakistan Muslim League Nawaz (PML-N), and Pakistan Tehrik-e-Insaf (PTI) tried their best to issue party tickets to women candidates as compared to 2008 and 2013 general elections. For this purpose, in July 2018 general elections, political parties of Pakistan finalized their women candidates name for the seats of National Assembly of Pakistan. The three leading political parties i.e., PTI, PPPP and PML-N issued their women candidates list in which the PTI issued party tickets to 14 females out of 244 candidates, PPPP give 12 out of 176 and PML-N confirmed 5 out of 125 candidates.

Similarly, they also issued party tickets to women candidates for Provincial Assemblies, in which PPPP finalized a total of 19 women candidates, and PML-N and PTI gave total of 11 tickets to women candidates as established by Election Act 2017. It is important to mention here that in the 2013 general elections a total of 61 party tickets were issued to women and the number of independent women candidates were 74 . While in the general election of 2008, total 41 woman got party tickets and 31 women candidates decided to contest elections independently. But the importance of 2002 elections cannot be overlooked because these elections provided an opportunity to educated women. General Pervaiz Musharraf made it conditional that who want to contested elections for national and provincial assembly must have a bachelor's degree. As a result, many seasonal ministers became ineligible to contest elections and benefited the educated people including women. The Musharraf government took steps for women empowerment by increasing the reserved seats to $17 \%$ for women and keeping $33 \%$ quota for woman in local bodies elections (Awan, 2018). Before 2018 general elections delimitation was made according to which some changes were made but no changes were made in the total number of seats for the National Assembly. The changes made in the reserved seats were filled through proportional representation. So, due to delimitation for Punjab total of 141 seats allowed and take seven seats, no changes were made in the seats of Sindh which are 61; in the share of Khyber Pakhtunkhwa came extra four seats so it become total of 39 seats; FATA, gained total twelve seats, in the share of Baluchistan two seats came due to which its seats reached to 16 seats; and the Federal Capital Islamabad gaining one seat and its total seats reached to 3 NA seats (www.vifindia.org).

Generally, in the 2018 general elections, the electoral participation of women on general seats remained well. In these general elections, 171 women contested general elections in 2018 from 122 different constituencies in which 115 women contestants got their party tickets for elections and the remaining 64 women opted to contest elections independently. In the general election 2018, 08 became successful in winning their seats, 09 got second position and 15 women got third position. As compared to 2013 general elections women electoral participation on general seats remained well as compared to party ticket which were very low. Total 4671 
candidates contested the general elections 2013 from 105 different constituencies out of which 147 women contested elections and the percentage was $3.14 \%$. Out of 147 women candidates, 61 women got the party tickets to contest election and the remaining 86 women decided to contest election independently. In this general elections, 08 women were able to win their seats, 15 women got second position and 09 got third position. (www.ecp.org.pk)

The political parties of Pakistan for the 60 reserved seats nominated women candidates. Then these reserved seats given according to the seats-strength they win in the NA. In these 60 seats 35 seats were given to Punjab, Sindh 14, Khyber Pakhtunkhwa 08, and Baluchistan 03.

\subsection{Women electoral participation on General Seats as well as on reserved seats for the Provincial Assembly of Punjab}

Total 103 women from Punjab contested general election for PA on reserved seats from 91 different constituencies. For the Punjab provincial assembly, the political parties issued party tickets to 62 women candidates while 45 women decided to contest elections independently. In the PAs general election 2018, 06 women candidates won the election, 09 women stood as runner-up and 06 got third position in their constituencies. As compared to the 2013 elections of Punjab, 171 women contested election, 09 women became successful in winning their seats, 04 came on second position and 07 got the third position. Similarly, the political parties of Pakistan for the 66 reserved nominated their women candidates.

\subsection{Women electoral participation on General Seats as well as on reserved seats for the Provincial Assembly of Sindh}

Total 97 women from Sindh candidates contested general elections from 70 different constituencies. The political parties from Sindh province issued party tickets to 63 women while 38 women contested elections independently. In the general elections of 2013, 02 women won the election, 04 women got second position and 03 came on third position in Provincial Assembly. Similarly, the political parties of Pakistan for the 29 reserved seats nominated their women candidates.

\subsection{Women electoral participation on general seats as well as on Reserved Seats for the Provincial Assembly of Khyber Pakhtunkhwa}

Total 38 women candidates from KP contested general elections on reserved seats from 31 different constituencies. The political parties from Khyber Pakhtunkhwa issued party tickets to 32 women while 07 women contested election independently. In the general elections 2018, for Provincial Assembly no women won the election, no women stood as runner-up and 03 got the third position in their constituencies. As compared to 2013 the general elections of Khyber Pakhtunkhwa, 29 women contested election and no woman became came out victorious. The political parties of Pakistan for the 22 reserved seats nominated women candidates.

\subsection{Women electoral participation on general seats as well as on Reserved Seats for the Provincial Assembly of Baluchistan}

Total 30 women from Baluchistan candidates contested general elections from 19 different constituencies. The political parties of Baluchistan issued party tickets to 20 women while 10 
women candidates contested election independently. In these elections no woman won the seats while only one got $2^{\text {nd }}$ position and 03 got $3^{\text {rd }}$ position. In the 2013 general elections, for provincial assembly, 11 women candidates contested elections in which only one woman won the seat and 07 got third position in their constituencies. The political parties of Pakistan for the 11 reserved seats nominated women candidates (www.ecp.org.pk)

\subsection{An analysis of the "decades of democracy" in Pakistan (2002 - 2018)}

The duration of the National Assembly from 2002 to 2018 and the Senate from $2002-2018$ will be remembered as a "decade of democracy" in Pakistan because all the four regimes in Pakistan were able to complete their five-year tenure. During the decade every government transferred power to other governments in a democratic way. These four general elections brought many changes in the politics of Pakistan as we saw women participated in the electoral process side by side with men. Another feature of these elections are as that voter's turnout increased to $53.62 \%$ in 2013 as compared to other elections. Similarly, completion of fiveyears duration of the four governments (Malik et al., 2019).

Pakistan got independence in 1947 but its women are still facing unequal treatment. The main reason behind this neglected behaviour are some factors in which the first one is socio-cultural norms as in our conservative and patriarchal society women have no right came out from the home environment and use her political right. Another factor is religious and political according to which the fundamental stratum and feudal dominated politics kept the women using her legal rights (Butt \& Shahid, 2012). There are a total 342 seats for the National Assembly of Pakistan in which 69 women are present in the NA, 60 represent the reserved seats, 8 women become able to win general seats, and one woman becomes successful on a minority seat. So, only $19.8 \%$ of women now represent the half population of Pakistan (Malik et al., 2019). When Pakistan came into being experiences started with women political representation and the most important change brought by General Pervaiz Musharraf in the shape of the 2002 Legal Framework Order. The $17^{\text {th }}$ amendment was also passed by his government, according to which 60 reserved seats provided for women in the NA while 17 in the Senate (Aurat Foundation, 2012). The highest proportion of women was recorded during 2008-2013 which was 22.5\%. It was due to the efforts on the part of the Election Commission of Pakistan (ECP) that the registration ratio of woman was recorded at $46 \%$ in 2002 and $44 \%$ from 2008-2018. This change started from 2002 general election and reached to peak in the 2018 general election when 171 women contested general election for NA in which 08 women were successful to win their seats. Still the percentage of women's representation in parliament decreased from $22.5 \%$ in the 2008 to $20 \%$ in 2018. The democratic decades from 2002 to 2018 also witnessed increased pro-women laws passed and the most important law was passed for transgenders in which protection provided to this stratum and now they can participate in the political process as well (Malik et al., 2019). Another important development for women's political participation was the Election Act 2017 in which more power given to ECP to reject the result of that constituency where turnout is less or equal to $10 \%$. ECP became empowered to criminalize those actions of the society which are held responsible for creating hurdles in the way of women political participation and directed political parties to allocate at least 5\% general seats to woman in National Assembly and Provincial Assembly elections. To increase women voter's registration and arrangement for the political participation of women, religious minorities, and disabled persons also came in the responsibilities of ECP (Mirbahar \& Simm, 2018). 
Assessment of woman political participation in 2018 Elections and its comparison ...

Table-5: Shows comparison of female turnout in Pakistan provinces/regions in GEs 2002-2018

\begin{tabular}{|l|c|c|c|c|}
\hline Province / Region & $\begin{array}{c}\text { Turnout in 2018 } \\
(\%)\end{array}$ & $\begin{array}{c}\text { Turnout in 2013 } \\
(\%)\end{array}$ & $\begin{array}{c}\text { Turnout in 2008 } \\
(\%)\end{array}$ & $\begin{array}{c}\text { Turnout in 2002 } \\
(\%)\end{array}$ \\
\hline Punjab & 53 & 60 & 48 & 42 \\
\hline $\begin{array}{l}\text { Khyber Pakhtunkhwa } \\
\text { Including FATA) }\end{array}$ & 35 & 45 & 34 & 33 \\
\hline Sindh & 43 & 54 & 44 & 37 \\
\hline Baluchistan & 40 & 43 & 31 & 29 \\
\hline Total & 52 & 55 & 44 & 39 \\
\hline
\end{tabular}

Sources: Aurat Foundation, legislative watch and Gilani's Index of Electoral Record, based on ECP data computed by Gallup Pakistan

It was never seen in the electoral history of Pakistan that gender-disaggregated voters' turnout was recorded. During 2018 general elections according to Section 91 of the Elections Act 2017 the polled votes of men and women were recorded separately on Form-45 (Result of the Count) and Form-47 (Provisional Consolidated Statement of Results of the Count). From this data it is concluded that $56.01 \%$ of men and $46.89 \%$ of women used their right to vote for National Assembly (NA), (FAFEN, 2018). Due to these political developments a high number of women and transgenders candidates participated in the election process of 2018. The following comparison of 2002, 2008, 2013, and 2018 general elections would clarify the number of women contested as well as elected on general seats.

Table-5 shows the number of women contested as well as the number of women elected on general seats in the National Assembly from 2002- 2018 general elections (Khan, 2018).

Table-6: List of women candidates vs women elected on General Seats in NA from 2002-2018

\begin{tabular}{|l|c|c|c|}
\hline S.\#. & Election Year & $\begin{array}{c}\text { Number of Women candidates on } \\
\text { General Seats }\end{array}$ & $\begin{array}{c}\text { Number of Women elected on } \\
\text { General Seats }\end{array}$ \\
\hline 01 & 2002 & 61 & 13 \\
\hline 02 & 2008 & 72 & 16 \\
\hline 03 & 2013 & 135 & 09 \\
\hline 04 & 2018 & 171 & 08 \\
\hline
\end{tabular}

Sources: Khan (2018) and www.ecp.gov.pk

Gender gap still exists in Pakistan. One of the reasons is cultural norms and values followed by our people. They always barred women from using their political rights and creating hurdles in their way. The gender gap can be concluded by comparing the registered votes of both the genders from 2002 to 2018 :

Table-7: List of electoral gender gaps from 2002 to 2018

\begin{tabular}{|l|l|l|l|l|l|l|}
\hline $\begin{array}{l}\text { S. } \\
\text { no. }\end{array}$ & Election Year & $\begin{array}{l}\text { Total Male } \\
\text { Voters }\end{array}$ & $\begin{array}{l}\text { Total } \\
\text { Women } \\
\text { Voters }\end{array}$ & Total Voters & Gender Gap & $\begin{array}{l}\text { Percent of } \\
\text { women } \\
\text { voters (\%) }\end{array}$ \\
\hline 01 & 2002 & $38,753,737$ & $33,160,113$ & $71,913,850$ & 559,3624 & 46 \\
\hline 02 & 2008 & $45,097,818$ & $35,409,553$ & $80,507,371$ & 968,8265 & 44 \\
\hline 03 & 2013 & $48,593,537$ & $37,596,214$ & $86,189,751$ & $1,099,7323$ & 44 \\
\hline 04 & 2018 & $59,224,263$ & $46,731,146$ & $105,955,409$ & $12,493,117$ & 44 \\
\hline
\end{tabular}

and Data of 2018 election added from ECP website. 
Despite the efforts of all the institutions including NGOs, civil society, parliament and ECP to increase registration as well as the turnout of woman voters but still the ratio remained $44 \%$ from 2008 to 2018 and the gender gap reached to 12.5 million in 2018 because more male voters cast their votes as compared to women voters. (www.tribune.com.pk).

\section{Conclusion}

If there is sustainability and consolidation of the democratic process, then a greater harmony between aspirations of the constituents and the parliamentary performance can be observed. General elections are considered as the backbone of democracy and democracy flourish if there is equal participation of citizens without any gender discrimination. Being $50 \%$ parts of the population women can only participate in state affairs when they have equal rights with men. In Pakistan, the Decade of Democracy started with at the beginning of 21 st century. The period from 2002-2018 is important in the sense that NAs completed their five-year tenures and power was peacefully transferred from one elected government to the other government.

The first general election of the $21^{\text {st }}$ Century was the 2002 election which was the first step towards the journey of women's electoral empowerment as out of 1170 total seats, there were 232 women in the legislature. After the elections, 27 women won the general seats and 205 were indirectly elected on women reserved seats, the percentage of representation was $20 \%$ which was a record never existed in the political history of Pakistan. Similarly, general elections were held on May 11, 2008, and according to ECP the total turnout of GE 2008 was $45 \%$, males registered voters were 45.3 million as compared to females which were 35.6 million, almost 10 million less than male voters. For the $2008 \mathrm{GE}$ total 205 women contested elections in which 79 women contested for NA and the remaining 126 women contested for four PAs. After the election 27 women out of 205 won the general seats. From Khyber Pakhtunkhwa total of 03 women contested general elections for NA and 12 for PA but no one can win the seat.

After successful tenure completion of the 2008 elected government, other elections were held for 2013. For the general elections of 2013 a total of 86 million voters were registered of which 37.5 million were females as compared to 48.5 million males with a gender disparity of 10 million. Total 147 women contested for NA, in which 09 women won the elections and 11 out of 301 women for the four PAs won the elections. In the elections of 2018, the national voters turnout decreased marginally from $53.62 \%$ to $51.99 \%$. However, as many as 8.45 million more voters have cast their votes as compared to the elections of 2013. The elections of 2018 also witnessed an unprecedented increase in the voters' registration since the election of 1970. The number of voters had increased from 86.19 million in the elections of 2013 to 105.96 million in the elections of 2018. Moreover, 19.77 million voters were added to the electoral rolls between 2013 and 2018, which is 23\% increase in the five-years. These figures represent the largest increase in the number of voters between the duration of two elections in the recent history. In the 2018 general elections total of 171 women contested elections in which 08 women won the seats. From the four PAs a total of 268 women contested GE in which 08 women won their seats. From Khyber Pakhtunkhwa, 38 women contested elections, but no woman won the seat. The voters in the age limit between 18-35 years are described as young voters and this voters group forms 43.82 percent of total the voters. The number of young voters increased by more than 2 million between 2013 and 2018. 


\section{References}

Aurat Foundation. (2012). Published under Legislative Watch Programme of Women's Empowerment

Awan, D. Z. (July 17, 2018). Under-representation of women.

Bano, S. (2009). Women in Parliament of Pakistan: Problems and potential solutions. Women's Studies Journal, 23(1), 19-35. http://wsanz.org.nz/journal/docs/WSJNZ231Bano1935.pdf

Shahid, J. (2012). Position of Pakistani women in 21st century: a long way to go. The Journal of Political Science, 30, 69-98. http://ps.gcu.edu.pk/wp-content/uploads/2015/02/Dr.Khalid-Manzoor-Butt.pdf

Check, J., \& Schutt, R. (2012). Survey research. Sage Publications.

Choudhary, R. (2018). Issues and challenges of women participation in politics. National Journal of Multidisciplinary Research and Development, 3(1), 344-346.

Dastageer, G., Zaidi, S., \& Safdar, R. (2018, Sep 18). A look into the turnout of women voters for the 2018 elections. Dawn. https://herald.dawn.com/news/1398671

FAFEEN-Women and the 2013 General Election-April 22, 2013. p. 05.

FAFEEN-Women and the 2013 General Elections-April 22, 2013. P. 05.

FAFEN'S Election Observation Report Voter Turnout in GE 2018, August 12, 2018.

Habermas, J. (1991). The public sphere. In C. Mukerji, \& M. Schudson (Ed.), Rethinking popular culture: Contemporary perspectives in cultural studies. (pp.398-404). University

California. http://pu.edu.pk/images/journal/csas/PDF/13\%20Arfan\%20Latif_30_2.pdf

Khan, I. A. (2018, July 6). Record number of 171 women in the run for NA general seats. Dawn. https://www.dawn.com/news/1418269

Imran, M. (2018, December 14). Women in Elections 2018 report launched. The News. https://www.thenews.com.pk/print/405563-women-in-elections-2018-report-launched

Kausar, I. (2013, May 22). Pakistan-women-s-political-participation. https://www.centralasianonline.com/en_GB/a..../22/feature01.www.pakistanaffairs.pk/.../4405

Latif, A., Usman, A., Kataria, J. R., \& Abdullah, M. (2015). Female political participation in South Asia: a case study of Pakistan. South Asian Studies, 30(2), 201-213. http://journals.pu.edu.pk/journals/index.php/IJSAS/article/view/3014

Mahmood, S. (2018, August 28). An uphill battle: Women's participation in the 2018 Pakistan elections. South Asian Voices. https://southasianvoices.org/an-uphill-battle-womensparticipation-in-the-2018-pakistan-elections/

Malik, D., Akhtar, R., Ahmed, U. B. \& Hayat, F. (2019). Decade of democracy in Pakistan (2008 - 2018).

Mirbahar, H. N. \& Simm, A. (2018). Pakistan's Elections Act 2017: What you need to know. https://democracy-reporting.org/pakistans-elections-act-2017-what-you-need-toknow/

NCSW (2010). Gender Review of political framework for women political participation. p. 10. National Commission in the Status of Women. https://ncsw.gov.pk/SiteImage/Downloads/Gender\%20Review\%20of\%20Framework \%20for\%20Women\%20Political\%20Participation.pdf

News Week. (2013, April 25). In Pakistan, millions of women voters may stay at home. Newsweekpakistan.com. https://www.newsweekpakistan.com/the-plight-of-pakistanswomen-voters/ 
Charmaz, K. (2006). Constructing grounded theory: A practical guide through qualitative analysis. Sage Publication.

Strauss, A., \& Corbin, J. (1998). Basics of qualitative research techniques. Sage Publication

The Tabeer. (218). Background paper The Elections Act, 2017: An overview. https://pakvoter.org/wp-content/uploads/2018/06/Overview-of-Elections-Act2602184.pdf

Waseem, M. (2006). Democratization in Pakistan: A study of the 2002 election. Oxford University.

Yousaf, H. (2013, May 04). In Pakistan millions of women voters may stay at home. Dawn. 